HALINA ZBOROŃ

$\stackrel{\circ}{\|}$

\title{
NIEKONTEKSTUALNE ROZUMIENIE KULTURY GOSPODARCZEJ
}

\begin{abstract}
Halina Zboroń, Niekontekstualne rozumienie kultury gospodarczej [Non-contextual understanding an economic culture] edited by W. Banach, M.A. Michalski, J. Sójka, "Człowiek i Społeczeństwo" vol. XLVI: Między Chinami a Zachodem. Pytanie o źródła chińskiego sukcesu gospodarczego [Between China and the West. An inquiry into the sources of the Chinese economic miracle], Poznań 2018, pp. 187-201, Adam Mickiewicz University. Faculty of Social Sciences Press. ISSN 0239-3271.
\end{abstract}

The article aims to critical analyze the way of understanding an economic culture, especially a contextual approach which characterizes economists' beliefs concerning as well economy as individuals participating in a social practice of production, exchange and consumption of goods and services. Moreover the author aims to present an alternative, non-contextual approach of an economic culture considered as a direct regulation of economic activities.

Halina Zboroń, Uniwersytet Ekonomiczny w Poznaniu, Katedra Socjologii i Etyki Gospodarczej, al. Niepodległości 10, 61-875 Poznań, e-mail: halina.zboron@ue.poznan.pl

\section{Wprowadzenie}

O kulturze w odniesieniu do gospodarki pisze się coraz częściej - notowany jest wyraźny wzrost zainteresowania problematyką kultury wśród ekonomistów. Świadczyć to może o poszerzaniu się kręgu badaczy uznających treści kulturowe za istotny składnik oddziałujący na procesy gospodarcze. Mam tu na myśli te teksty, w których expressis verbis pojawiają się określenia „kultura gospodarcza”, „czynniki kulturowe”, 
„kulturowe uwarunkowania”, „wartości wyższe, światopoglądowe”, „pozaekonomiczne cele i motywacje”, „,instytucje społeczne”, „kulturowe wzory gospodarowania”, „reguły społeczne” itp. Jak pisze Jerzy Wilkin ${ }^{1}$, znaczący wzrost zainteresowania kulturą postrzeganą jako czynnik rozwoju gospodarczego, jaki można było zauważyć w latach czterdziestych i pięćdziesiątych XX w., związany był z aktywnością publikacyjną badaczy kultury (Margaret Mead, Ruth Benedict, Ralph Linton), którzy wykazywali znaczenie kultury w życiu społeczeństw. Kolejny przypływ zainteresowań dotyczących badań nad kulturą - zdaniem Wilkina - nastąpił w latach osiemdziesiątych, co z kolei należy wiązać z narastaniem znaczenia instytucjonalnego podejścia w naukach ekonomicznych. Na początku XXI w. ważnym dziełem postulującym zintensyfikowanie namysłu nad kulturą gospodarczą była zbiorowa monografia Culture Matters: How Values Shape Human Progress, a także prace Geerta Hofstedego oraz Charlesa Hampden-Turnera i Fonsa Trompenaarsa. Oczywiście, należy zauważyć, że w naukach o zarządzaniu badania odnoszące się do kulturowych podstaw organizacji gospodarczych mają długą tradycję, a zagadnienie różnic kulturowych traktowane jest jako ważny aspekt funkcjonowania przedsiębiorstw w odmiennych środowiskach.

W teorii zarządzania poszukuje się odpowiedzi na pytania dotyczące zagadnień mikroekonomicznych na temat sposobów funkcjonowania organizacji w różnych obszarach kulturowych i wpływu uwarunkowań kulturowych na efektywność ekonomiczną podmiotów gospodarczych. W ekonomii natomiast kwestie te odnoszone są do skali makroekonomicznej i globalnej. Włączenie zagadnień kulturowych związane było przede wszystkim z uznaniem czynników kulturowych za istotny element oddziałujący na rozwój społeczno-ekonomiczny, tym samym konstatacje dotyczące tych kwestii włącza się w poszukiwania wyjaśnień kwestii dysproporcji tempa wzrostu gospodarczego w skali porównań gospodarek narodowych czy regionów świata, co oczywiście wiąże się z ukonstytuowaniem się rynku światowego i gospodarki globalnej. Ważnym przyczynkiem dla podjęcia takiej refleksji była potrzeba odpowiedzi na pytanie, w jakim zakresie kultura warunkuje sposób pojmowania kategorii instytucjonalnych, na których bazuje system kapitalistycznej gospodarki rynkowej².

${ }^{1} \mathrm{~J}$. Wilkin, Instytucjonalne i kulturowe podstawy gospodarowania. Humanistyczna perspektywa ekonomii, Wydawnictwo Naukowe Scholar, Warszawa 2016, s. 80.

${ }^{2}$ Por. ibidem, s. 81. 
Cechą wspólną dla znakomitej większości tekstów dotyczących kultury odnoszonej do zagadnień ekonomicznych jest kontekstualne ${ }^{3}$ rozumienie kultury polegające na traktowaniu praktyki gospodarczej oraz przekonań kulturowych jako odrębnych obszarów realności społecznej. Stosownie do takiego rozumienia kultura stanowi zewnętrzny i przedmiotowo różny w stosunku do gospodarki obszar zjawisk. Traktowana jako jej otoczenie może na nią wpływać, wchodzić w różne zależności. Jak pisze Peter Berger, „z tego, że mówimy o kulturze gospodarczej, nie wynika wcale, że kultura zawsze determinuje gospodarkę ani że we wszystkich zjawiskach badanych przez ekonomistę należy uwzględniać czynniki kulturowe"”.

Celem podjętych tu rozważań jest dokonanie krytycznej analizy sposobu rozumienia kultury gospodarczej w tekstach ekonomistów, przede wszystkim zaś wykazanie, że jest ona rozumiana kontekstualnie, a zatem traktowana jako zewnętrzne otoczenie praktyki gospodarczej. Zauważmy, że takie ujęcie kultury gospodarczej znajduje oparcie w respektowanych w ekonomii przekonaniach przedmiotowych dotyczących zarówno gospodarki, jak i jednostki uczestniczącej w praktyce produkcji, wymiany i konsumpcji dóbr i usług. Podjęte analizy zmierzają do przedstawienia alternatywnego, niekontekstualnego ujęcia kultury gospodarczej jako bezpośredniego regulatora działań gospodarczych. Objaśnienie różnic pomiędzy tymi ujęciami zostało odniesione do założeń przedmiotowych i epistemologicznych przesądzających o charakterze realności praktyki społecznej (gospodarczej) oraz rozstrzygających kwestię jej dostępności poznawczej.

\section{Kontekstualne rozumienie kultury jako czynnika warunkującego praktykę gospodarczą}

Rosnąca liczba publikacji odnoszących się do problemu kulturowych uwarunkowań gospodarki, a także liczne - często mające charakter interdyscyplinarny - konferencje poświęcone tej problematyce skłaniają do przypuszczenia, że zagadnienie to stanowi swoiste wyzwanie poznawcze dla współczesnych badaczy społecznych. Sprawa jest z pewnością skomplikowana, dotyczy

${ }^{3}$ Zgodnie ze znaczeniem słownikowym przyjmuję, że kontekst to „zespół czynników współistniejących, powiązanych z czymś” (https://sjp.pwn.pl/szukaj/kontekst.html). Badania kontekstualne polegają na objaśnianiu jakiegoś zjawiska poprzez odniesienie go do warunkujących go czynników zewnętrznych.

${ }^{4}$ P. Berger, Rewolucja kapitalistyczna, Oficyna Naukowa, Warszawa 1995, s. 20. 
bowiem trzech różnych aspektów: przedmiotowego, metodologicznego i światopoglądowego (etycznego). Badacze podejmujący problem „kultura a gospodarowanie” odnoszą się zatem do następujących pytań: czy praktyka gospodarcza jest uwarunkowana kulturowo?; czy w badaniach nad zjawiskami gospodarczymi należy uwzględniać (ewentualne) zależności kulturowe?; czy zachowania decydentów oraz rezultaty i następstwa ich działań mogą być oceniane nie tylko w odniesieniu do wartości ekonomicznych, ale także światopoglądowych, etycznych? Co ciekawe, wydaje się, że zbiory osób zainteresowanych tymi problemami są w zasadzie rozłączne $e^{5}$. Mam tu na myśli sytuację, w której zwolennicy przekonania o istotnym wpływie kultury na zjawiska i procesy gospodarcze podejmujący refleksję dotyczącą zagadnień przedmiotowej charakterystyki zjawisk gospodarczych nie dokonują rozstrzygnięć co do metod (procedur) umożliwiających uwzględnianie wpływu czynników kulturowych. Powoduje to dość specyficzną sytuację polegającą na tym, że badacze ci i ich adwersarze prowadzą dyskusje na innych polach: pierwsi odnoszą się do kwestii przedmiotowych, drudzy koncentrują się przede wszystkim na kwestiach metodologicznych, przy czym wymiana poglądów dokonuje się w obrębie teorii ekonomicznych lub na ogólniejszym poziomie filozofii ekonomii. Jeśli chodzi zaś o trzecią grupę - rzeczników przekonania o zasadności formułowania sądów etycznych dotyczących zagadnień praktyki gospodarczej - zdają się oni tworzyć osobne tematycznie grono osób często repezentujących pozaekonomiczne dyscypliny naukowe. Warto podkreślić, że wspólnym mianownikiem dla wszystkich wskazanych tu grup badaczy jest to, iż podejmując różne aspekty zagadnienia kultury gospodarczej, pojmują ją kontekstualnie. Spośród wskazanych powyżej trzech problemów uszczegóławiających kwestię uwarunkowania kulturowego podjęte zostanie jedynie pytanie o zasadność uwzględniania treści kulturowych w przedmiotowej charakterystyce zjawisk ekonomicznych.

Kontekstualne ujmowanie kultury uznawanej za czynnik rozwoju gospodarczego i społecznego polega na traktowaniu jej jako uwarunkowania egzogenicznego, zewnętrznego wobec gospodarki. Przyjmuje się zatem, że procesy gospodarcze mogą być zależne (w jakimś stopniu) od „otoczenia kulturowego” lub „otoczenia kulturowego i instytucjonalnego”. Tym samym odniesienie się do treści kulturowych ma się przyczyniać do lepszego zrozumienia procesów gospodarczych oraz zachowań podmiotów rynkowych

\footnotetext{
${ }^{5}$ Jest to wrażenie autorki, które nie jest poparte jakimiś dogłębnymi analizami treści wypowiedzi dyskutantów, ale mające ugruntowanie jedynie w dotychczasowym doświadczeniu jako czytelnika tekstów ekonomicznych.
} 
pozostających pod wpływem określonych przekonań upowszechnionych w danej społeczności ${ }^{6}$.

O kontekstualnym traktowaniu kultury świadczy to, że w przekonaniu zwolenników poszerzenia zakresu interpretacji zjawisk gospodarczych uwzględnianie określonych (uznanych za ważne) treści kulturowych stanowi dopełnienie (często traktowane jako istotne) procedur poznawczych stosowanych w ekonomii. Odniesienie do przekonań kulturowych jest zatem traktowane jako uzupełnienie, wzbogacenie procedury wyjaśniania ekonomicznego. Wskazuje się także na nieoczywisty, niejednoznaczny charakter czynników ekonomicznych, na przykład takich cech podmiotowych, jak przedsiębiorczość, pracowitość, skłonność do ryzyka, oszczędność, zaangażowanie, wytrwałość w osiąganiu celów, zdolność do rywalizacji, które są istotne zarówno w praktyce gospodarczej, jak i poza nią.

Osobnym problemem jest kwestia znaczenia nadawanego pojęciu „kultura” i „kultura gospodarcza”. Jeśli chodzi o pierwsze pojęcie, większość badaczy nie przywołuje objaśnień definicyjnych; można sądzić, że przyjmują słownikowe czy encyklopedyczne znaczenia. Berger stwierdza natomiast, że denotacją określenia „kultura gospodarcza” jest społeczno-kulturowy kontekst aktywności gospodarczej i funkcjonowania instytucji gospodarczych. Wydaje się, że objaśnienie to znaleźć może zastosowanie w odniesieniu do innych autorów wypowiadających się na temat kulturowych uwarunkowań gospodarki. Pewną zagadką jest natomiast to, co rozumie się pod pojęciem „czynnik kulturowy”. Jakie konkretnie treści, czy raczej jaki typ przekonań uznaje się za mający (mogący mieć) wpływ na zjawiska gospodarcze? Na trudność tę wskazują Jerzy Hausner, Anna Karwińska i Jacek Purchla: „Kultura to bardzo złożony obszar rzeczywistości społecznej. Nie tylko dlatego, że obejmuje tak wiele elementów. Przede wszystkim dlatego, że jej relacje z innymi składowymi systemu społecznego są wielowymiarowe i kompleksowe. Także w płaszczyźnie, która nas w tej publikacji szczególnie interesuje, a mianowicie na polu związków kultury i gospodarki oraz - szerzej - rozwoju społeczno-gospodarczego"7.

${ }^{6}$ Przykładem takiego ujęcia jest program badawczy Kultura i rozwój, realizowany w Instytucie Studiów Zaawansowanych w latach 2012-2016. Celem tego programu (konferencji, seminariów, badań naukowych) było zbadanie potencjału kultury w stymulowaniu rozwoju społeczno-gospodarczego. Ważnym intelektualnym wkładem w rozważania teoretyczne są pozycje literaturowe z serii Kultura się liczy! oraz debaty Kultura i rozwój, które organizowane były dzięki współpracy Collegium Civitas oraz Narodowego Centrum Kultury.

7 J. Hausner, A. Karwińska, J. Purchla (red.), Kultura a rozwój, Narodowe Centrum Kultury, Warszawa 2013, s. 14. 
Analiza wypowiedzi badaczy uznających potrzebę (konieczność, pożytek - różnie jest to ujmowane) odnoszenia się w badaniach nad gospodarką do treści przekonań kulturowych mających - ich zdaniem wpływ na podmioty gospodarcze (sposób rozumienia świata oraz działania w określony sposób: decydowania o celach i sposobach ich osiągania) prowadzi do wniosku, że biorą oni pod uwagę przede wszystkim obszar kultury symbolicznej: obyczaj (w tym moralność), religię (szerzej światopogląd), zwyczaje lokalne, tradycje i utrwalony obraz przeszłości danego narodu czy regionu ${ }^{8}$. Odrębnym zagadnieniem jest refleksja dotycząca związku gospodarki i kultury artystycznej, która obecnie stanowi w pewnym stopniu wyodrębniony obszar badań ekonomicznych zwanych ekonomią kultury czy przemysłami kultury (culture industry). W takich przypadkach poddaje się analizie zagadnienie pozytywnego oddziaływania pewnych form obecności dzieł sztuki i artystów w przestrzeni publicznej na rozwój społeczno-gospodarczy ${ }^{9}$. Wykazuje się, że kultura artystyczna (tym bardziej przemysły kultury) może być uznana za źródło rozwoju społeczno-ekonomicznego. Przykładem rozważań tego typu są prace Richarda Floridy, który wykazuje dodatnie sprzężenie między potencjałem kultury i „klasą kreatywną” a rozwojem społeczno-ekonomicznym miast ${ }^{10}$.

Konstatacja skłonności badaczy ekonomistów do zawężania idei kultury do jej sfery symbolicznej nasuwa wyjaśnienie istnienia pewnej ambiwalencji, jaką daje się zauważyć: z jednej strony bowiem podtrzymują oni

${ }^{8}$ Podobną obserwację poczynił Arjo Klamer, który analizuje zagadnienie odwoływania się do określonych wartości w pracach ekonomistów. Charakterystyczne dla ekonomistów neoklasycznych sytuowanie wartości w obszarze kultury symbolicznej powoduje, że podtrzymywany w głównym nurcie ekonomii wymóg neutralności aksjologicznej jest oparty na błędnym przekonaniu, iż uwarunkowanie działań gospodarczych ze względu na wartość ekonomiczną może być postrzegane jako mechaniczny proces pozbawiony moralnych, społecznych i kulturowych konotacji. Zob. A. Klamer, A Reevaluation of Values in Economics, 2003, www.klamer.nl/articles/culture/revaluation.php, dostęp: 10.09.2012.

${ }^{9}$ Przykładem może być idea miasta kreatywnego wykorzystującego kulturę dla tworzenia warunków rozwojowych.

${ }^{10}$ Warto dodać, że w późniejszym okresie (wywiad z 2015 r.) Florida uzupełnił skonstruowany w Narodzinach klasy kreatywnej obraz zmian rozwojowych ośrodków miejskich, które dokonują się pod wpływem rozrastania się klasy kreatywnej. Podtrzymując tezę o istotnym pozytywnym wpływie twórczej klasy średniej na wzrost ekonomiczny, wskazał na jednoczesne pogłębianie się nierówności społecznych silnie zaznaczających się w gospodarkach kreatywnych. 
przekonanie, że działalności człowieka nie można traktować rozłącznie od kultury - człowiek podlegający socjalizacji przyswaja wszakże treści określonej kultury, które działają jako regulatory jego zachowań, z drugiej jednak strony wyrażają wątpliwości, czy istotnie oddziaływanie czynników kulturowych (rozumianych jako treści kultury symbolicznej) na praktykę gospodarczą jest bezpośrednie i przemożne. Wątpliwości te przeradzają się w przekonanie, że w odniesieniu do zjawisk gospodarczych należy mówić o splocie różnych okoliczności, występowaniu zróżnicowanych uwarunkowań: obiektywnych warunków, na które składają się niezależne od kultury prawa ekonomii wraz z układem zdarzeń obejmujących stany uprzednie, aktualne i prognozowane oraz owe „miękkie” czynniki pozaekonomiczne, kulturowe.

Drugim powodem dla ostrożnościowego oceniania wpływu kultury na praktykę gospodarczą jest skłonność ekonomistów do identyfikowania zależności przyczynowo-skutkowej, co utrudnia, czy wręcz uniemożliwia uwzględnianie czynników, których nie daje się ująć ilościowo. Osobną kwestią jest zróżnicowanie postaci oddziaływania oraz mnogość kanałów przepływu treści kulturowych, co powoduje określone problemy z jednoznaczną identyfikacją zakresu wpływu. Dobrą ilustracją tej obserwacji może być wypowiedź jednego z badaczy analizujących zagadnienie relacji kultura a gospodarka:

Szukając komponentów kultury ekonomicznej, należy zdawać sobie sprawę
z tego, że każde konkretne działanie podmiotu gospodarującego jest zawsze
pochodną dwóch czynników: motywów i bodźców o ściśle ekonomicznym
charakterze (opisanych w prawach ekonomicznych rządzących procesami
gospodarczymi) oraz czynników pozagospodarczych (np. wartości, zwy-
czajów, norm społecznych itp.). Te drugie składają się właśnie na kulturę
ekonomiczną; wywierają wpływ na sferę gospodarczą, nie przy-
należą do niej jednak ze swej istoty (Kulturowe aspekty..., s. 62).
Są efektem ustaleń poczynionych na płaszczyźnie etycznej, moralnej, a nie
wynikiem rachunku ekonomicznego lub przejawem troski ludzi o własny
interes. Czynniki ekonomiczne i pozagospodarcze działają łącznie; dążenie
do maksymalizacji korzyści indywidualnych współistnieje z kulturowym,
społecznym i moralnym uwarunkowaniem zachowań ludzkich ${ }^{11}$.

W wypowiedzi tej ujawnia się stanowiące przedmiot mojego zainteresowania kontekstualne rozumienie kultury gospodarczej.

${ }^{11}$ K. Kostro, Zagadnienia kulturowe w ekonomii, „,Gospodarka Narodowa” 230(3)/2009, s. 37. 


\section{(Nie)obecność rozważań o kulturze w głównym nurcie ekonomii}

Należy podkreślić, że zagadnieniem rozważanym w tym tekście nie jest pytanie o związki kultury i gospodarki, ale o to, w jaki sposób kwestia ta jest reflektowana w obszarze nauk społecznych, w szczególności ekonomicznych. Jak zostało to już wyżej zauważone, kulturę ujmuje się jako kontekst, okoliczności, które mogą - mniej lub bardziej zauważalnie wpływać na gospodarkę. Kultura jest w istocie sprowadzana do węższego bądź szerszego zestawu tzw. czynników kulturowych, które uznaje się za znaczące w zakresie oddziaływania na zjawiska ekonomiczne. Podejmowanie zagadnienia wpływu „zewnętrznych uwarunkowań” (tak to jest określane) może być uznane z jednej strony za skutek krytycznej oceny podejścia dominującego w ekonomii, opartego na kanonicznych założeniach ekonomii neoklasycznej, z drugiej zaś - może stanowić próbę wprowadzenia pewnej korekty do konstruowanego zgodnie z tymi założeniami obrazu świata gospodarczego.

Dokonane przez neoklasyków ustalenia dotyczące przedmiotowych przekonań filozoficznych o „naturze” badanej rzeczywistości: zjawisk ekonomicznych i człowieka ujmowanego jako podmiot gospodarujący, stanowiące kanoniczne założenia głównego nurtu ekonomii, od dawna są dość ostro krytykowane. Nade wszystko krytykowane jest zredukowanie człowieka gospodarującego do modelowego homo oeconomicus, który zdaniem krytyków jest traktowany jako wyobcowana społecznie i wykorzeniona kulturowo jednostka, niemająca nic wspólnego z realnymi podmiotami uwikłanymi w relacje społeczne i kierującymi się złożonymi motywacjami. Podobnie - akulturowo - pojmowany jest system wymiany rynkowej. Reguły gry rynkowej traktuje się jako względnie niezależne od pozostałych obowiązujących pozaekonomicznych reguł społecznych, a obszar działań gospodarczych jako wyłączony z gry ogólnospołecznej.

Dyskusje co do sposobu uprawiania ekonomii opartej na kanonicznych założeniach dominującej w głównym nurcie ekonomii neoklasycznej rozpoczęły się już w XIX w. za sprawą heterodoksyjnych szkół historycznej i instytucjonalnej, które - inaczej niż ekonomia neoklasyczna wzorująca się na fizyce i korzystająca z osiągnięć logiki i matematyki inspirowane były socjologią, antropologią kulturową oraz historią gospodarczą. Heterodoksi uznają, że pomijanie przez neoklasyków ważnych z punktu widzenia społeczeństwa aspektów gospodarowania prowadzi do 
„zniekształcania całości perspektywy poznawczej tej nauki” ${ }^{12}$. Co więcej w opinii oponentów - prowadzi to do kryzysu ekonomii i wyczerpania jej zdolności eksplanacyjnych ${ }^{13}$. Janusz Stacewicz komentuje to w następujący sposób:

To właśnie w związku z charakterem założeń leżących u podstaw ekonomii neoklasycznej powstaje problem jej związku z rzeczywistością. Założenia idealizacyjne, upraszczające rzeczywistość gospodarczą, czy też wręcz naginające ją do aparatu formalno-matematycznego, sprawiają bowiem, że konstrukcje teoretyczne, do których to prowadzi, mają charakter typów idealnych. Nie odwzorowują one zatem rzeczywistości, a stanowią jedynie narzędzia ułatwiające jej porządkowanie poprzez określenie ram, w obrębie których mieszczą się rozwiązania rzeczywiste ${ }^{14}$.

Wypowiedź ta jest reprezentatywna dla obozu krytyków ekonomii neoklasycznej. Główny ciężar zarzutów dotyczy kwestii tzw. nierealistycznych założeń przedmiotowych. Propagatorzy uwzględniania treści kulturowych w badaniach nad gospodarką uzasadniają to potrzebą zerwania z „upraszczającym, wyabstrahowanym z życia społecznego, niepełnym, nierzeczywistym” sposobem postrzegania tego obszaru. Uwzględnienie kontekstu, jakim jest otoczenie kulturowe - w ich przekonaniu - ma pozwolić na „dopełnienie, urealnienie” naukowego obrazu, który będzie stanowił „bardziej adekwatną” reprezentację zjawisk gospodarczych. Przykładem takich rozważań jest tekst

${ }^{12}$ A. Glapiński, Meandry historii ekonomii. Między matematykq a poezja, Oficyna Wydawnicza Szkoły Głównej Handlowej w Warszawie, Warszawa 2006, s. 28.

${ }^{13}$ Są wśród nich R. Solow, A. Blinder, R. Lipsey, M. Friedman, W. Leontief, których opinie przytaczają R.S. Goldfarb i T.C. Leonard w pracy Economics at The Millennium z 2002 r. Tradycyjnie krytyczna wobec ekonomii głównego nurtu jest D. McCloskey, ale także M. Blaug, P. Krugman, D. Acemoglu, T. Lawson, D. Colander, U. Mäki. R. Solow ostrzegał, że zaufanie ekonomistów do technicznego modelowania na wzór fizyki może prowadzić do bagatelizowania ontologicznej różnicy między fizykalnymi i społecznymi zjawiskami. T. Lawson (The Current Economic Crisis: Its Nature and the Course of Academic Economics, „Cambridge Journal of Economics” 2009, nr 33), B. Fine (Social Capital versus Social Theory. Political Economy and Social Science at the Turn of the Millennium, Routledge, London 2001) krytykowali ekonomię za oddalenie się od społecznych realiów i niewykorzystywanie możliwości metodologii nauk społecznych. D. Acemoglu (The Crisis of 2008: Structural Lessons for and from Economics, Centre for Economic Policy Research „Policy Insight” 28/2009) i autorzy ważnego, często przytaczanego tekstu The Financial Crisis and the Systemic Failure of Academic Economics (2009) przekonują, że kryzys gospodarczy ujawnił metodologiczną słabość ekonomii.

${ }^{14}$ J. Stacewicz, W kierunku metaekonomii, Oficyna Wydawnicza Szkoły Głównej Handlowej, Warszawa 2003, s. 25. 
George'a Akerlofa The Missing Motivation in Macroeconomics ${ }^{15}$. Autor, przywołując założenia nowej ekonomii klasycznej, wykazuje, że zostały one sformułowane niezależnie od obserwacji realnych podmiotów dokonujących wyborów ekonomicznych, co spowodowało pominięcie ważnego ich aspektu, tj. wpływu norm społecznych na zachowania uczestników praktyki gospodarczej. Zakorzenione w jednostkach przekonania dotyczące powinności (religijnych, etycznych) prowadzą - zdaniem Akerlofa - do znaczącej modyfikacji (korekty) zachowań, które zgodnie z założeniami modelowymi prowadzić mają do maksymalizowania korzyści. Podjęta przez tego badacza (a także przez Amartyę Sena i Alberta Hirschmana) próba odniesień do wartości niematerialnych - w ocenie Klamera ${ }^{16}$ - nie może być uznana za satysfakcjonującą. Oto bowiem niezależnie od pragnień, dopóki nie odrzucają oni założenia o racjonalności, dopóty pozostają im dwie możliwości: uwzględnienie takich, a nie innych wartości w funkcji użyteczności lub traktowanie ich jako ograniczenia.

Ramy prowadzonych tu rozważań nie pozwalają na przedstawienie dyskusji pomiędzy stronami reprezentującymi różne podejście do zagadnienia uwzględniania uwarunkowań kulturowych w przedmiotowych charakterystykach zjawisk z obszaru zainteresowań ekonomiii ${ }^{17}$. Należy jednak zauważyć, że badacze wypowiadający się krytycznie wobec przedmiotowych założeń kanonicznych ekonomii głównego nurtu podważają respektowany w jego obrębie obraz gospodarki, zgodnie z którym gospodarka stanowi system względnie niezależny i względnie izolowany w stosunku do pozostałych obszarów społecznych. Decydujące znaczenie w kwestii przebiegu procesów gospodarczych mają prawa ekonomii, obiektywne zachowania podmiotów gospodarujących są determinowane silnie oddziałującymi mechanizmami rynkowymi, skłaniającymi jednostki do działania, które może przynieść im korzyści. Zabieganie o uzyskanie jak największych

${ }_{15}$ G.A. Akerlof, The Missing Motivation in Macroeconomics, „The American Economic Review” 97(1)/2007.

${ }^{16}$ A. Klamer, A Reevaluation of Values in Economics, 2003, www.klamer.nl/articles/ culture/revaluation.php, dostęp: 10.09.2012.

${ }^{17}$ Kwestie te zostały szerzej omówione w tekstach: H. Zboroń, Teorie ekonomiczne w perspektywie konstruktywizmu społecznego, Wyd. Uniwersytetu Ekonomicznego w Poznaniu, Poznań 2009; eadem, Dyskurs metodologiczny we współczesnej ekonomii próba dekonstrukcji podejścia modernistycznego, „Studia Ekonomiczne” 1/2013; eadem, Podział nauk a status i miejsce ekonomii, „Studia Ekonomiczne” 3/2014; B. Scheuer, Metodologia ekonomii w perspektywie konstruktywistycznej, Wyd. Uniwersytetu Ekonomicznego we Wrocławiu, Wrocław 2015. 
korzyści jest z kolei przejawem egoistycznej natury człowieka. Rzecznicy zmian, które mają polegać na poszerzeniu analiz zjawisk gospodarczych o treści dotychczas traktowane jako egzogeniczne, są przekonani, że wzbogacenie materiału badawczego o kulturowe, instytucjonalne otoczenie pozwoli na uzyskanie pełniejszych wyjaśnień, które nie będą odnosić się do sytuacji laboratoryjnych ${ }^{18}$, ale do realnych procesów, których rzeczywisty przebieg zależy od splotu wielu czynników zarówno ekonomicznych, jak i pozaekonomicznych ${ }^{19}$.

Pewnym problemem jest jednak to, że dyskusja dotycząca założeń respektowanych przez przedstawicieli podejścia neoklasycznego prowadzona jest na warunkach przez nich ustalonych, tj. toczy się w ramach paradygmatu głównego nurtu i tym samym w obrębie określonego dyskursu narzucającego właściwą sobie retorykę. Tym samym krytyka podejścia neoklasycznego dotycząca nieuwzględniania uwarunkowań kulturowych zjawisk gospodarczych budowana jest na przekonaniu o kontekstualnym, tj. zewnętrznym wobec praktyki gospodarczej usytuowaniu przekonań kulturowych. Kontekstualne ujmowanie kultury gospodarczej jest przykładem myślenia, które wpisuje się w modernistyczną tradycję uprawiania ekonomii wyznaczoną paradygmatem neoklasycznym.

Alternatywą dla takiego ujęcia może być niekontekstualne ujęcie kultury gospodarczej realizowane w ramach osadzonej na fundamencie przekonania o genetycznym pierwszeństwie kultury koncepcji kulturoznawstwa gospodarczego.

\section{Niekontekstualne badania nad kulturą gospodarowania - idea kulturoznawstwa gospodarczego}

Kulturoznawstwo gospodarcze jest tu rozumiane jako dziedzina wiedzy, której obszarem przedmiotowym jest kultura gospodarowania w znaczeniu zestawu respektowanych społecznie przekonań ustanawiających cele i wartości-sensy działań gospodarczych, a także sposób ich osiągania. Idea badań ekonomicznych pojmowanych jako badania nad kulturą gospodarowania sytuuje się

${ }^{18}$ Taki charakter mają de facto ustalenia dokonywane w badaniach z wykorzystaniem modeli - wyabstrahowanych obrazów realnych zjawisk.

${ }^{19}$ Argument dotyczący „pełniejszego”, „bardziej realistycznego” opisu i wyjaśniania zjawisk ekonomicznych odnosi się do metodologicznego sporu pomiędzy zwolennikami podejścia instrumentalnego i realistycznego. 
w podejściu konstruktywizmu kulturowego uznającego, że rzeczywistość jest tworzona społecznie, a to, co uznajemy za świat, który w potocznym doświadczeniu wydaje się istnieć obiektywnie, tj. niezależnie od ludzkiej aktywności, jest w istocie konstruktem wytwarzanym w zbiorowym doświadczeniu. Przekonanie to jest fundamentem stanowiska konstruktywistycznego, które kwestionując realizm poznawczy, również w wersji krytycznej, zaprzecza, jakoby rzeczywistość była dostępna poznawczo inaczej jak poprzez wytarzane kulturowo kategorie poznawcze. Doświadczenie rzeczywistości jest zatem aktem kulturowym, co oznacza, że kultura umożliwia i jednocześnie warunkuje zarówno jego przebieg, jak i wynik. Konstruktywistyczne stanowisko ma dwa wymiary: przedmiotowy - ontologiczny i podmiotowy - poznawczy.

Taki konstruktywistyczny pogląd odnajdujemy w kulturoznawczej teorii społecznej Jerzego Kmity. Zgodnie z nią rzeczywistość istnieje w dwóch wymiarach: praktycznym (przedmiotowym) i myślowym (podmiotowym). Pierwszy z nich - praktyka społeczna - to ogół czynności podejmowanych przez członków danej społeczności, przy czym sposób realizowania tych czynności jest zgodny z respektowanymi w danej społeczności wzorcami. Myślowa realność z kolei to system przekonań, których podstawowymi typami są przekonania przedmiotowe (rozstrzygające, co i jak istnieje oraz jakie ma cechy), przekonania epistemologiczne (wskazujące możliwości poznania) oraz przekonania aksjologiczne, światopoglądowe (wyznaczające wartości i cele nadrzędne). Praktyka społeczna oraz sfera przekonań społecznych, czyli kultura, tworzą razem rzeczywistość społeczną. Ogół czynności praktycznych uporządkowanych jest w grupy wyspecjalizowanych praktyk, którym odpowiadają systemy regulatywne przekonań, stanowiące dziedziny kultury. Jednostki należące do danej społeczności są świadome, że istnieją społecznie aprobowane cele i sposoby ich osiągania, oraz wiedzą, że skuteczność ich działania jest warunkowana respektowaniem reguł społecznych. Podejmując działania będące następstwem respektowania reguł kulturowych, przyczyniają się do odtwarzania rzeczywistości przedmiotowej i jednocześnie utrwalania realności myślowej, świadomości zbiorowej. Społecznie jest konstruowana zatem nie tylko realność świata, ale także rozumienie tej realności. Świat istnieje więc i jest rozpoznawany w obrębie kultury. Dotyczy to również gospodarowania.

Konstruktywizm w odniesieniu do aspektu epistemologicznego przyjmuje, że uzyskiwana wiedza na temat świata odnosi się do konstruowanych w tym poznaniu przedmiotów. Innymi słowy, to, jaki jest dany przedmiot zainteresowania badaczy (środowiska naukowego), jest warunkowane charakterystycznymi dla tego środowiska instrumentami wytwarzającymi 
ów przedmiot i kontekstami, w których jest on ujmowany. Poznajemy tylko to, co możemy poznać, i tylko w taki sposób, jaki jest możliwy: przez „kulturowe okulary”. Przedmiotami poznania są jedynie obiekty należące do obiektywnego ludzkiego świata, a ich prezentacja w akcie poznawczym ujawnia ich kulturową postać.

Rzeczywistość gospodarcza nie jest ujmowana wprost w bezpośrednim doświadczeniu. Przedmiot poznania jest postrzegany poprzez pryzmat podzielanych społecznie przesądzeń o rzeczywistości - co oznacza, że przystępujemy do badania zjawisk z pewną gotową o nich (przed)wiedzą, która poprzedza nasze rozpoznanie (stanowi składnik procesu poznawczego) i wpływa na uzyskane wyniki.

Konsekwencją podejścia konstruktywistycznego jest odrzucenie kontekstualnego rozumienia kultury, tj. ujmowania jej jako czynnika zewnętrznego wobec opisywanych zjawisk. Niekontekstualne ujęcie kultury gospodarczej polega na rozumieniu, że jest ona fundamentem, podstawą działań, które są podejmowane i realizowane, a ich rezultaty są konstytuowane zawsze w obrębie oddziaływania kultury, nigdy poza nim. Kultura ma więc moc konstytuowania zjawisk, a nie jedynie wpływania na nie, modyfikowania czy korygowania. Świat społeczny jest realnością wewnątrzkulturową - człowiek jest podmiotem aktywnie oddziałującym na swoje otoczenie: tworzy własne środowisko i nadaje kulturowy sens wyobrażeniom rzeczywistości. Wszelkie rozumienie rzeczywistości odnosi się do świata ukonstytuowanego społecznie: wewnątrzkulturowego „ludzkiego świata obiektywnego” ${ }^{20}$. Poznawanie tego świata polega tym samym na rozpoznaniu jego kulturowego fundamentu.

Przedstawione tu podejście może wydawać się radykalne zwłaszcza w odniesieniu do stanowiska ekonomii ortodoksyjnej. Przyjmuje się bowiem, że kultura jest podstawą wszelkiego działania sytuowanego w obszarze praktyki społecznej. Mówienie zatem, że zjawiska gospodarcze mogą podlegać wpływowi czynników kulturowych, to zdecydowanie zbyt ostrożne podejście, choć - jak wiadomo - nawet w takiej, ograniczonej, postaci jest niechętnie przyjmowane w środowisku ekonomistów. Niewielu badaczy ekonomistów jest skłonnych uznać rolę przekonań kulturowych w konstytuowaniu się zjawisk gospodarczych, a absolutnie wyjątkowe jest podzielanie przedstawionego tu ujęcia kulturowo-konstruktywistycznego. Przykładem może być holenderski badacz Arjo Klamer, który konsekwentnie od wielu lat prowadzi badania w perspektywie kulturowej. W jednym ze swoich

${ }^{20}$ Określenie Anny Pałubickiej, która reprezentuje podejście kulturowo-konstruktywistyczne. 
tekstów ${ }^{21}$ zwraca uwagę, że pogląd, iż wartości pełnią kluczową rolę w procesach gospodarczych, jest traktowany jako zasadny nawet w zdroworozsądkowym oglądzie, tymczasem w ekonomii zdominowanej przez teorię racjonalnego wyboru wartościom nadaje się status subiektywny i odnosi się je do kwestii preferencji, co do których przyjmuje się, że są stałe. Klamer objaśnia proces zmian, jakie dokonały się w myśleniu ekonomicznym i które doprowadziły do tego, że wartość ekonomiczna zaczęła być postrzegana jako wynik mechanicznego procesu wzajemnych oddziaływań między podażą i popytem. Podejście Marshallowskie ostatecznie pozbawiło wartości ekonomiczne ich moralnych, społecznych i kulturowych konotacji. Zdaniem Klamera wiele jest do zrobienia, jeśli chodzi o rozpoznanie wpływu różnych wartości (rozpoznawanych jako zmienne historycznie i kulturowo dookreślone) na zjawiska i procesy gospodarcze. Możemy natomiast oczekiwać - według tego badacza że uzyskamy możliwość głębszego i istotniejszego rozumienia tego obszaru.

\section{Podsumowanie}

Ewidentny wzrost zainteresowania zagadnieniem wpływu uwarunkowań kulturowych na gospodarkę może być łączony z wieloma kwestiami. Jedną z nich jest z pewnością toczona od lat dyskusja na temat kanonicznych założeń ekonomii głównego nurtu, która z kolei jest wyrazem niepokojów dotyczących kierunku i tempa rozwoju ekonomii. Jak zostało przedstawione wyżej, znaczenie kultury w odniesieniu do badań nad gospodarką ma co najmniej trzy wymiary: przedmiotowy, metodologiczny i etyczny. Problemów odnoszących się do tych trzech zagadnień nie daje się rozstrzygnąć, dopóki pozostajemy w kręgu założeń paradygmatu ortodoksyjnego i racjonalności naukowej modernizmu. Bez rozstrzygających odpowiedzi pozostają pytania podstawowe: czy zjawiska gospodarcze są kulturowo określone?; czy należy owe kulturowe aspekty, charakterystyki uwzględnić w badaniach, czy można je pominąć jako nieistotne?; czy jest możliwe rozstrzygnięcie tych kwestii, tj. czy jest możliwe poznanie realności jako takiej (także w wersji realizmu krytycznego)?; jakie argumenty przemawiające za odnoszeniem praktyk gospodarczych do norm i reguł etycznych można zasadnie przedstawić? Dopóki będziemy traktować kulturę jako kontekst (tj. uwarunkowania zewnętrzne), dopóty dyskusje na temat ważności oraz zakresu owego kontekstu będą nadal się toczyć, bez szans na uzyskanie konsensu.

\footnotetext{
${ }^{21}$ A. Klamer, A Reevaluation of Values...
} 


\section{Literatura}

Acemoglu D., The Crisis of 2008: Structural Lessons for and from Economics, Centre for Economic Policy Research „Policy Insight” 28/2009.

Akerlof G.A., The Missing Motivation in Macroeconomics, „The American Economic Review” 97(1)/2007.

Berger P., Rewolucja kapitalistyczna, Oficyna Naukowa, Warszawa 1995.

Colander D., Föllmer H., Haas A., Goldberg M., Juselius K., Kirman A., Lux T., Sloth B., The Financial Crisis and the Systemic Failure of Academic Economics (Discussion Papers Department of Economics University of Copenhagen 2009, no. 09-03.

Fine B., Social Capital versus Social Theory. Political Economy and Social Science at the Turn of the Millenium, Routledge, London 2001.

Florida R., Do diabła z klasq kreatywnq, 2015, http://publica.pl/teksty/florida-do-diabla-zklasa-kreatywna-53182.html, dostęp: 12.11.2017.

Glapiński A., Meandry historii ekonomii. Między matematykq a poezjq, Oficyna Wydawnicza Szkoły Głównej Handlowej w Warszawie, Warszawa 2006.

Goldfarb R.S., Leonard T.C., Economics at the Millennium, „Social Science and Modern Society" 40(1)/2002.

Hausner J., Karwińska A., Purchla J. (red.), Kultura a rozwój, Narodowe Centrum Kultury, Warszawa 2013.

Klamer A., A Pragmatic View on Values in Economics, „Journal of Economic Methodology” 10(2)/2003.

Klamer A., A Reevaluation of Values in Economics, 2003, www.klamer.nl/articles/culture/ revaluation.php, dostęp: 10.09.2012.

Kmita J., Kultura i poznanie, Państwowe Wydawnictwo Naukowe, Warszawa 1985.

Kmita J., O kulturze symbolicznej, Centralny Ośrodek Metodyki Upowszechniania Kultury, Warszawa 1982.

Kochanowicz J., Mandes S., Marody M. (red.), Kulturowe aspekty transformacji ekonomicznej, Instytut Spraw Publicznych, Warszawa 2007.

Kostro K., Zagadnienia kulturowe w ekonomii, „Gospodarka Narodowa” 230(3)/2009.

Lawson T., The Current Economic Crisis: Its Nature and the Course of Academic Economics, „Cambridge Journal of Economics” 33/2009.

Scheuer B., Metodologia ekonomii w perspektywie konstruktywistycznej, Wyd. Uniwersytetu Ekonomicznego we Wrocławiu, Wrocław 2015.

Stacewicz J., W kierunku metaekonomii, Oficyna Wydawnicza Szkoły Głównej Handlowej, Warszawa 2003.

Szahaj A., Nauki o kulturze jako nauki podstawowe i krytyczne, „Filo-Sofija” 12(1)/2011.

Wilkin J., Instytucjonalne i kulturowe podstawy gospodarowania. Humanistyczna perspektywa ekonomii, Wydawnictwo Naukowe Scholar, Warszawa 2016.

Zboroń H., Dyskurs metodologiczny we współczesnej ekonomii - próba dekonstrukcji podejścia modernistycznego, „Studia Ekonomiczne” 1/2013.

Zboroń H., Podział nauk a status i miejsce ekonomii, „Studia Ekonomiczne” 3/2014.

Zboroń H., Teorie ekonomiczne w perspektywie konstruktywizmu społecznego, Wyd. Uniwersytetu Ekonomicznego w Poznaniu, Poznań 2009. 
